\title{
Graft-versus-Host Disease
}

\author{
James L.M. Ferrara, M.D. ${ }^{,}{ }^{*}$, John E. Levine, M.D. ${ }^{b}$, Pavan Reddy, M.D.C, and Ernst Holler, \\ M.D.d \\ aUniversity of Michigan, Pediatrics and Internal Medicine, Blood and Marrow Transplantation \\ Program \\ bUniversity of Michigan, Pediatrics and Internal Medicine, Blood and Marrow Transplantation \\ Program \\ 'University of Michigan, Internal Medicine, Blood and Marrow Transplantation Program \\ dInternal Medicine and Department of Haematology/Oncology, University Hospital, Regensburg, \\ Germany
}

\section{Introduction}

The number of allogeneic hematopoietic cell transplantations (HCT) continues to increase with more than 25,000 allogeneic transplantations performed annually. The graft-versusleukemia / tumor (GVL) effect during allogeneic HCT effectively eradicates many hematological malignancies. 1 The development of novel strategies that use donor leukocyte infusions, non-myeloablative conditioning and umbilical cord blood (UCB) transplantation have helped expand the indications for allogeneic HCT over the last several years, especially among older patients. 2 Improvements in infectious prophylaxis, immunosuppressive medications, supportive care and DNA-based tissue typing have also contributed to improved outcomes after allogeneic HCT.1 Yet the major complication of allogeneic HCT, graft-versus-host disease (GVHD), remains lethal and limits the use of this important therapy.2 Given current trends, the number of transplants from unrelated donors is expected to double within the next five years, significantly increasing the population of patients with GVHD. In this seminar we review advances made in identifying the genetic risk factors and pathophysiology of this major HCT complication, as well as its prevention, diagnosis and treatment.

\section{Etiology and Clinical Features}

Fifty years ago Billingham formulated three requirements for the development of GVHD: the graft must contain immunologically competent cells; the recipient must express tissue antigens that are not present in the transplant donor; and the recipient must be incapable of mounting an effective response to eliminate the transplanted cells. ${ }^{3}$ We know now that the immunologically competent cells are T cells, and that GVHD can develop in various clinical settings when tissues containing $\mathrm{T}$ cells (blood products, bone marrow, and solid organs) are transferred from one person to another who is not able to eliminate those cells. ${ }^{4}, 5$ Patients, whose immune systems are suppressed, and who receive white blood cells from another individual, are at particularly high risk for GVHD.

GVHD occurs when donor T cells respond to genetically defined proteins on host cells. The most important proteins are Human Leukocyte Antigens (HLA)2, 6, 7, which are highly

\footnotetext{
"Corresponding Author: James L.M. Ferrara, M.D., The University of Michigan, 1500 East Medical Center Drive, 6303 CCC, Ann Arbor, MI 48109-5942, Telephone: (734)615-1340, FAX (734)615-4947, email: ferrara@umich.edu..
} 
polymorphic and are encoded by the major histocompatibility complex (MHC). Class I HLA (A, B, and C) proteins are expressed on almost all nucleated cells of the body at varying densities. Class II proteins (DR, DQ, and DP) are primarily expressed on hematopoietic cells (B cells, dendritic cells, monocytes), but their expression can be induced on many other cell types following inflammation or injury. High-resolution DNA typing of HLA genes with polymerase chain reaction (PCR)-based techniques have now largely replaced earlier methods. The incidence of acute GVHD is directly related to the degree of mismatch between HLA proteins8, 9 and thus ideally, donors and recipients are matched at HLA-A, $\mathrm{B}$, -C, and -DRB1, (" $8 / 8$ matches"), but mismatches may be tolerated for UCB grafts (see below). $10^{-} 12$

Non-HLA Genetics-Despite HLA identity between a patient and donor, approximately $40 \%$ of patients receiving HLA-identical grafts develop acute GVHD due to genetic differences that lie outside the HLA loci, or "minor" histocompatibility antigens (HA). Some minor HAs, such as HY and HA-3, are expressed on all tissues and are targets for both GVHD and GVL. ${ }^{13}$ Other minor HAs, such as HA-1 and HA-2, are expressed most abundantly on hematopoietic cells (including leukemic cells) and may therefore induce a greater GVL effect with less GVHD.13, 14

Polymorphisms in both donors and recipients for cytokines that are involved in the classical 'cytokine storm' of GVHD (discussed below) have been implicated as risk factors for GVHD. ${ }^{15}$ Tumor Necrosis Factor (TNF)- $\alpha$, Interleukin 10 (IL-10), Interferon- $\gamma$ (IFN $\gamma$ ) variants have correlated with GVHD in some, but not all, studies.16¹8 Genetic polymorphisms of proteins involved in innate immunity, such as nucleotide oligomerization domain 2 and Keratin 18 receptors, have also been associated with GVHD.19-22 Future strategies to identify the best possible transplant donor will probably incorporate both HLA and non-HLA genetic factors.

Clinical Features of Acute GVHD: Based on an early Seattle experience, acute GVHD was defined to occur prior to day 100, whereas chronic GVHD occurred after that time. 23-25 This definition is far from satisfactory, and a recent National Institutes of Health classification includes late-onset acute GVHD (after day 100) and an overlap syndrome with features of both acute and chronic GVHD. ${ }^{26}$ Late-onset acute GVHD and the overlap syndrome occur with greater frequency after reduced-intensity conditioning (RIC), an increasingly widespread technique (see below). As shown in Table 1, the clinical manifestations of acute GVHD occur in the skin, gastrointestinal tract and liver. ${ }^{27}$ In a comprehensive review, Martin et al found that at the onset of acute GVHD, $81 \%$ of patients had skin involvement, $54 \%$ had GI involvement, and 50\% had liver involvement. ${ }^{23}$ Recent data suggest that lungs might also be targets of experimental GVHD. ${ }^{28}$

Skin is most commonly affected and is usually the first organ involved, often coinciding with engraftment of donor cells. The characteristic maculopapular rash is pruritic and can spread throughout the body, sparing the scalp (Figure 1). In severe cases the skin may blister and ulcerate. ${ }^{27}$ Apoptosis at the base of epidermal rete pegs is a characteristic pathologic finding. Other features include dyskeratosis, exocytosis of lymphocytes, satellite lymphocytes adjacent to dyskeratotic epidermal keratinocytes, and a perivascular lymphocytic infiltration in the dermis. ${ }^{29}, 30$

Gastrointestinal tract involvement of acute GVHD usually presents as diarrhea but may also include vomiting, anorexia, and/or abdominal pain when severe. ${ }^{29}$ The diarrhea of GVHD is secretory and often voluminous (greater than two liters per day). Bleeding, which carries a poor prognosis, occurs as a result of mucosal ulceration ${ }^{31}$ but patchy involvement of the mucosa often leads to a normal appearance on endoscopy. 32 
Radiologic findings of the gastrointestinal (GI) tract include luminal dilatation with thickening of the wall of the small bowel ("ribbon sign" on CT scan) and air/fluid levels suggestive of an ileus. ${ }^{27}$ Histologic features include patchy ulcerations, apoptotic bodies in the base of crypts, crypt abscesses, and loss as well as flattening of the surface epithelium.33

Liver disease caused by GVHD may be difficult to distinguish from other causes of liver dysfunction following BMT such as veno-occlusive disease, drug toxicity, viral infection, sepsis, or iron overload. The histologic features of hepatic GVHD are endothelialitis, lymphocytic infiltration of the portal areas, pericholangitis and bile duct destruction. ${ }^{34,35}$ The liver is rarely biopsied because thrombocytopenia early after transplant greatly increases the risks of the procedure, usually making the diagnosis one of exclusion.

The incidence of the severity of acute GVHD is determined by the extent of involvement of these three principal target organs (see Table 1). The overall grades are classified as I (mild), II (moderate), III (severe) and IV (very severe). Severe GVHD carries a poor prognosis, with $25 \%$ long term survival for grade III and $5 \%$ for grade IV. ${ }^{36}$

The incidence of acute GVHD is directly related to the degree of mismatch between HLA proteins and ranges from $35-45 \%$ in recipients of full matched sibling donor grafts ${ }^{8,9}$ to $60-80 \%$ in recipients of one-antigen HLA mismatched unrelated donor grafts. ${ }^{6,}, 37-39$ The same degree of mismatch causes less GVHD using UCB grafts and incidence of acute GVHD is lower following the transplant of partially matched UCB units and ranges from $35-65 \% .^{12}$

Clinical Features of Chronic GVHD: Chronic GVHD is the major cause of late nonrelapse death following HCT. ${ }^{40}$ Its presentation may be progressive (active or acute GVHD merging into chronic), quiescent (acute GVHD that resolves completely but is later followed by chronic GVHD) or it may occur de novo. Older recipient age and a history of acute GVHD are the greatest risk factors for chronic GVHD, ${ }^{41}$ and strategies to prevent acute GVHD may therefore help to prevent chronic GVHD. As shown in Table 2, the manifestations of chronic GVHD are somewhat protean, and are often of an autoimmune nature. Clinical signs often first appear in the buccal mucosa (see Figure 2). New consensus criteria for the diagnosis and staging of chronic GVHD have recently been developed. ${ }^{26}$

Pathophysiology of Acute GVHD: Two important principles are important to consider regarding the pathophysiology of acute GVHD. First, acute GVHD reflects exaggerated but normal inflammatory mechanisms mediated by donor lymphocytes infused into the recipient where they function appropriately, given the foreign environment they encounter. Second, the recipient tissues that stimulate donor lymphocytes have usually been damaged by underlying disease, prior infections, and the transplant conditioning regimen. ${ }^{29}$ As a result, these tissues produce molecules (sometimes referred to as "danger" signals) that promote the activation and proliferation of donor immune cells. ${ }^{42-} 45$ Mouse models havebeen central to our identification and understanding of the pathophysiologic mechanisms of GVHD, and canine models have been critical to the development of clinically useful strategies for GVHD prophylaxis and treatment and to the development of donor leukocyte infusions.36, 46,47 Based largely on these experimental models, the development of acute GVHD can be conceptualized in three sequential steps or phases: (1) activation of the APCs; (2) donor T cell activation, proliferation, differentiation and migration; and (3) target tissue destruction (Figure 3).

Phase I: Activation of Antigen Presenting Cells (APCs): The first step involves the activation of APCs by the underlying disease and the HCT conditioning regimen. Damaged host tissues respond by producing "danger" signals, including proinflammatory cytokines 
(e.g., TNF- $\alpha$ ), chemokines, and increased expression of adhesion molecules, MHC antigens and costimulatory molecules on host APCs. $42,48^{-} 50 \mathrm{~A}$ recent report demonstrated that at one week after HCT, increased levels of TNF- $\alpha$ receptor I, a surrogate marker for TNF- $\alpha$, strongly correlated with the later development of GVHD.51 Damage to the GI tract from the conditioning is particularly important because it allows for systemic translocation of additional inflammatory stimuli such as microbial products including lipopolysaccaride (LPS) or other pathogen-associated molecular patterns that further enhance the activation of host APCs. ${ }^{49}$ The secondary lymphoid tissue in the GI tract is likely the initial site of interaction between activated APCs and donor T cells.52 These observations have led an important clinical strategy to reduce acute GVHD by reducing the intensity of the conditioning regimen. Experimental GVHD can also be reduced by manipulating distinct subsets of APCs.53,54 In addition, non-hematopoietic stem cells, such as mesenchymal stem cells or stromal cells, can reduce allogeneic $\mathrm{T}$ cell responses, although the mechanism for such inhibition remains unclear. ${ }^{2}$

The concept that enhanced activation of host APCs increases the risk for acute GVHD unifies a number of seemingly disparate clinical associations with that risk, such as advanced stages of malignancy, more intense transplant conditioning regimens and histories of viral infections. APCs detect infections by recognizing conserved molecular patterns that are unique to microbes, called pathogen-associated molecular patterns (PAMPs). Among the classes of receptors that recognize such patterns, the Toll-like receptors (TLR) are the best characterized.55 For example, TLR4 recognizes LPS55 and mice with mutant TLR4 receptors that do not respond to LPS cause less GVHD when used as donors.56 Other TLRs that recognize viral DNA or RNA also activate APCs and may enhance GVHD, providing a potential mechanistic basis for increased GVHD associated with viral infections such as cytomegalovirus (CMV).57

Phase II: Donor T Cell Activation: The core of the GVH reaction is Step 2, where donor T cells proliferate and differentiate in response to host APCs. The "danger" signals generated in Phase I augment this activation at least in part by increasing the expression of costimulatory molecules. ${ }^{58}$ Blockade of co-stimulatory pathways to prevent GVHD is successful in animal models, but this approach has not yet been tested in large clinical trials. 2

In mouse models, where genetic differences between donor and recipient strains can be tightly controlled, $\mathrm{CD}^{+}$cells induce acute GVHD to MHC class II differences, and $\mathrm{CD} 8^{+}$ cells induce acute GVHD to MHC class I differences. ${ }^{59-61}$ In the majority of HLA-identical HCTs, both $\mathrm{CD}^{+}{ }^{+}$and $\mathrm{CD} 8^{+}$subsets respond to minor histocompatibility antigens and can cause GVHD in HLA-identical HCT.

Regulatory T cells can suppress the proliferation of conventional T cells and prevent GVHD in animal models when added to donor grafts containing conventional T cells.62 In mice, the Foxp3 protein functions as a master switch in the development of regulatory $\mathrm{T}$ cells, which normally constitute $5 \%$ of the CD4+ T cell population. ${ }^{62}$ Regulatory $\mathrm{T}$ cells secrete antiinflammatory cytokines IL-10 and Transforming Growth Factor(TGF)- $\beta$ and can also act through contact-dependent inhibition of APCs. ${ }^{62}$ It is likely that the use of regulatory T cells in clinical acute GVHD will require improved techniques to identify and expand them.

Natural Killer T cell (NKT) $1.1^{+}$subsets of both the host and donors that have been shown to modulate acute GVHD. ${ }^{63}$ Host NKT cells have been shown to suppress acute GVHD in an IL-4 dependent manner. ${ }^{64} \mathrm{~A}$ recent clinical trial of total lymphoid irradiation used as conditioning significantly reduced GVHD and enhanced host NKT cell function. ${ }^{65} \mathrm{By}$ 
contrast, donor NKT cells can reduce GVHD and enhance perforin mediated GVL in an experimental model. ${ }^{66}$

Activation of immune cells results in rapid intracellular biochemical cascades that induce transcription of genes for many proteins including cytokines and their receptors. Th1 cytokines (IFN- $\gamma$, IL-2 and TNF- $\alpha$ ) are produced in large amounts during acute GVHD. IL-2 production by donor $\mathrm{T}$ cells remains the principal target of many current clinical therapeutic and prophylactic approaches to GVHD, such as cyclosporine, tacrolimus and monoclonal antibodies (mAbs) directed against IL-2 and its receptor. ${ }^{9}$ But emerging data indicate an important role for IL-2 in the generation and maintenance of $\mathrm{CD} 4^{+} \mathrm{CD} 25^{+} \mathrm{T}$ regs, suggesting that prolonged interference with IL-2 may have an unintended consequence of preventing the development of long term tolerance after allogeneic HCT. ${ }^{67}$ IFN- $\gamma$ has multiple functions and can either amplify or reduce GVHD. ${ }^{68,69}$ IFN- $\gamma$ may amplify GVHD by increasing the expression of molecules such as chemokines receptors, MHC proteins, and adhesion molecules; it also increases the sensitivity of monocytes and macrophages to stimuli such as LPS and accelerates intracellular cascades in response to these stimuli. ${ }^{70}$ Early polarization of donor T cells so that they secrete less IFN- $\gamma$ and more IL- 4 can also attenuate experimental acute GVHD. ${ }^{71}$ IFN- $\gamma$ may amplify GVHD by directly damaging epithelium in the GI tract and skin and inducing immnosuppression through the induction of nitric oxide. ${ }^{72}$ By contrast, IFN- $\gamma$ may suppress GVHD by hastening the apoptosis of activated donor T cells. ${ }^{69}, 73$. This complexity means the manipulation of IFN- $\gamma$ may have diverse effects in vivo, making it a challenging target with respect to therapeutic intervention. IL-10 plays a key role in suppression of immune responses, and clinical data suggest it may regulate acute GVHD. ${ }^{17}$ TGF- $\beta$, another suppressive cytokine can suppress acute GVHD but exacerbate chronic GVHD. ${ }^{74}$ Thus the timing and duration of the secretion of any given cytokine may determine the specific effects of that cytokine on GVHD severity.

Phase III: Cellular and Inflammatory Effector Phase: The effector phase of this process is a complex cascade of both cellular mediators such as cytotoxic $\mathrm{T}$ lymphocytes(CTLs) and NK cells and soluble inflammatory mediators such as TNF- $\alpha$, IFN- $\gamma$, IL- 1 and nitric oxide. ${ }^{2}$, 29 These soluble and cellular mediators synergize to amplify local tissue injury and further promote inflammation and target tissue destruction.

Cellular Effectors-The cellular effectors of acute GVHD are primarily CTLs and NK cells.49 CTLs that preferentially use the Fas/FasL pathway of target lysis and appear to predominate in GVHD liver damage (hepatocytes express large amounts of Fas) whereas GVHD CTLs that use the perforin /granzyme pathways are more important in the GI tract and skin.2, 75 Chemokines direct the migration of donor $\mathrm{T}$ cells from lymphoid tissues to the target organs where they cause damage. Macrophage inflammatory protein-1alpha (MIP-1 $\alpha$ ) and other chemokines such as CCL2-5, CXCL2, CXCL9-11, CCL17 and CCL27 are over-expressed and enhance the homing of cellular effectors to target organs during experimental GVHD.76 Expression of integrins, such as $\alpha 4 \beta 7$ and its ligand MadCAM-1, are also important for homing of donor T cells to Peyer's patches during intestinal GVHD. $52,77,78$

Inflammatory Effectors-Microbial products such as LPS that leak through a damaged intestinal mucosa or skin may stimulate secretion of inflammatory cytokines through Tolllike receptors (TLRs). ${ }^{49}, 79$ The GI tract is particularly susceptible to damage from TNF- $\alpha$, and plays a major role in the amplification and propagation of the "cytokine storm" characteristic of acute GVHD.49 TNF- $\alpha$ can be produced by both donor and host cells, and it acts in three different ways: first, it activates APCs and enhances alloantigen presentation; 
second, it recruits effector cells to target organs via the induction of inflammatory chemokines; and third, it directly causes tissue necrosis, as its name suggests. $80^{-82}$

Prevention of GVHD: Based on the evidence from animal models regarding the central role of T cells in initiating GVHD, numerous clinical studies evaluating T cell depletion (TCD) as prophylaxis for GVHD were performed in the 1980's and 1990's. There were three principal TCD strategies: (1) negative selection of T cells ex vivo, (2) positive selection of $\mathrm{CD} 34^{+}$stem cells ex vivo; and (3) anti-T cell antibodies in vivo. ${ }^{83}$ Most strategies showed a significant limitation in both acute and chronic GVHD. ${ }^{84-88}$ Unfortunately, the lower incidence of severe GVHD was offset by high rates of graft failure, relapse of malignancy, infections, and Epstein-Barr virus-associated lymphoproliferative disorders. Negative selection purging strategies using various anti-T cell antibodies achieved similar long-term results regardless of the breadth of antibody specificity. ${ }^{89-93}$ One large registry study demonstrated that purging strategies using antibodies with broad specificities produced inferior leukemia-free survival than standard immunosuppression in patients receiving unrelated donor transplants. ${ }^{94}$ Several studies have investigated partial T cell depletion, either by eliminating specific $\mathrm{T}$ cell subsets (e.g., $\mathrm{CD} 8^{+}$) or by titrating the dose of $\mathrm{T}$ cells present in the inoculum. ${ }^{95-97}$ None of these approaches, however, has convincingly demonstrated an optimal strategy that improves long-term survival.

Alemtuzumab is a monoclonal antibody that binds CD52, a protein expressed on a broad spectrum of leukocytes including lymphocytes, monocytes, and dendritic cells. Its use in GVHD prophylaxis in a Phase II trial decreased the incidence of acute and chronic GVHD following reduced intensity transplant. ${ }^{98}$ In two prospective studies, patients who received alemtuzumab rather than methotrexate showed significantly lower rates of acute and chronic GVHD,${ }^{99}$ but experienced more infectious complications and higher rates of relapse, so that there was no overall survival benefit. Alemtuzumab may also contribute to graft failure when used with minimal intensity conditioning regimens. ${ }^{100}$

An alternative strategy to TCD attempted to induce anergy in donor T cells by ex vivo antibody blockade of co-stimulatory pathways prior to transplantation. A small study using this approach in haploidentical HCT recipients was quite encouraging, but has not yet been replicated. ${ }^{101}$ Thus the focus of most prevention strategies remains pharmacological manipulation of $\mathrm{T}$ cells after transplant.

Administration of anti-T cell antibodies in vivo as GVHD prophylaxis has also been extensively tested. The best studied drugs are anti-thymocyte globulin (ATG) or antilymphocyte globulin (ALG) preparations. These sera, which have high titers of polyclonal antibodies, are made by immunizing animals (horses or rabbits) to thymocytes or lymphocytes, respectively. A complicating factor in determining the role of these polyclonal sera in transplantation is the observation that even different brands of the same class of sera exert different biologic effects. ${ }^{102}$ However, the side effects of ATG/ALG infusions are common across different preparations and include fever, chills, headache, thrombocytopenia (from cross-reactivity to platelets), and, infrequently, anaphylaxis. In retrospective studies, rabbit ATG reduced the incidence of GVHD in related donor HSCT recipients without appearing to improve survival.103, 104 In recipients of unrelated donor HSCT, addition of ALG to standard GVHD prophylaxis effectively prevented severe GVHD, but did not result in improved survival because of increased infections.105 In a long term follow-up study, however, pretransplant ATG provided significant protection against extensive chronic GVHD and chronic lung dysfunction.106

The primary pharmacologic strategy to prevent GVHD is the inhibition of the cytoplasmic enzyme, calcineurin, that is critical for in the activation of $\mathrm{T}$ cells. The calcineurin 
inhibitors, cyclosporine and tacrolimus, have similar mechanisms of action, clinical effectiveness and toxicity profiles, including hypomagnesemia, hyperkalemia, hypertension, and nephrotoxicity. 9,107 Serious side effects include transplant-associated thrombotic microangiopathy (TAM) and neurotoxicity that can lead to premature discontinuation. Although clinically similar to thrombotic thrombocytopenic purpura, TAM does not reliably respond to therapeutic plasmapheresis, carries a high mortality rate, and removal of the offending agent does not always result in improvement. ${ }^{108}$ Posterior reversible encephalopathy syndrome includes mental status changes, seizures, neurological deficits and characteristic magnetic resonance imaging findings; this syndrome has been seen in 1-2\% of HCT recipients receiving and calcineurin inhibitors.109 Side effects of these drugs decrease as the dose is tapered, usually two to four months after HCT.

Calcineurin inhibitors are often administered in combination with other immunosuppressants, such as methotrexate, which is given at low doses in the early posttransplant period.9, 107 The toxicities of methotrexate (neutropenia and mucositis) have led some investigators to replace it with mycophenolate mofetil (MMF). In one prospective randomized trial, patients who received MMF as part of GVHD prophylaxis experienced significantly less severe mucositis and more rapid neutrophil engraftment than those who received methotrexate. ${ }^{110}$ The incidence and severity of acute GVHD was similar between the two groups, but the study closed early due to superiority of the MMF arm with respect to reduced mucositis and the speed of hematopoietic engraftment. A desire for faster neutrophil engraftment has led to the use of MMF in UCB blood transplants where graft failure is a major concern.111 MMF is also often used after RIC regimens for similar reasons.112, 113

Sirolimus is an immunosuppressant that is structurally similar to tacrolimus but does not inhibit calcineurin. In a small Phase II trial, it showed excellent efficacy in combination with tacrolimus; ${ }^{114}$ the drug damages endothelial cells, however, and it may enhance TAM that is associated with calcineurin inhibitors. ${ }^{115}$ The combination of tacrolimus and sirolimus is currently being compared in a large randomized multi-center trial.

RIC regimens attempt to suppress the host immune system sufficiently so that donor T cells can engraft and then ablate the lympho-hematopoietic compartment of the recipient. The term "non-myeloablative" is therefore somewhat misleading. RIC regimens produce less tissue damage and lower levels of the inflammatory cytokines that are important in the initiation of GVHD pathophysiology; this effect may explain the reduced incidence of severe GVHD following RIC compared to the full intensity conditioning used in historical controls.98, 116 The onset of acute GVHD may be delayed after RIC until after day 100, however, and it may present simultaneously with elements of chronic GVHD ("overlap syndrome"). ${ }^{116-} 120$

Treatment of Acute GVHD: GVHD generally first develops in the second month after HCT, during continued treatment with calcineurin-based prophylaxis.23, ${ }^{121}$ Steroids, with their potent antilymphocyte and anti-inflammatory activity, are the gold standard for treatment of GVHD. Many centers treat mild GVHD of the skin (Grade I) with topical steroids alone, but for more severe skin GVHD and any degree of visceral GVHD involvement, high-dose systemic steroids are usually initiated. Steroid therapy results in complete remission in less than half of the patients, ${ }^{122}$ and more severe GVHD is less likely to respond to treatment.123, 124 In a prospective randomized study, the addition of ATG to steroids as primary therapy did not increase the response rate.124 In a retrospective study, the use of ATG in patients who showed early signs of steroid-resistance was beneficial, ${ }^{122}$ but not all studies show such benefit and ATG is not standardly used because of increased infection risks. ${ }^{106,125,126 .}$ 
An increasingly common treatment for GVHD is extracorporeal photopheresis (ECP). During ECP, the patient's white blood cells are collected by apheresis, incubated with the DNA-intercalating agent, 8-methoxypsoralen, exposed to ultraviolet light (UVA), and returned to the patient. ECP is known to induce cellular apoptosis, which has strong antiinflammatory effects in a number of systems, including prevention of rejection of solid organ grafts. ${ }^{127}$ Animal studies show that ECP reverses acute GVHD by increasing the number of regulatory T cells.128 A Phase II clinical study of steroid-dependent or steroid refractory GVHD showed resolution of GVHD in a large majority of patients, with 50\% long-term survival in this very high risk group.129 Randomized multi-center studies of this approach are needed to determine its place in the management of acute GVHD.

Another interesting strategy to treat GVHD is the blockade of the inflammatory cytokine TNF- $\alpha$. TNF- $\alpha$ can activate APCs, recruit effector cells and cause direct tissue damage. ${ }^{130}$ In animal models, TNF- $\alpha$ plays a central role in GVHD of the GI tract, which is central to the "cytokine storm" and plasma levels of TNFR I (a surrogate marker for TNF- $\alpha$ ) rise in patients before the clinical manifestations of GVHD appear. ${ }^{51} \mathrm{~A}$ recent Phase II trial of etanercept, a solubilized TNFR II, showed significant efficacy when added to systemic steroids as primary therapy for acute GVHD. Seventy percent of patients had complete resolution of all GVHD symptoms within one month, with $80 \%$ complete responses in the GI tract and the skin. The authors also showed that plasma levels of TNFR I were a significant biomarker for clinical GVHD.131

Treatment of Chronic GVHD: In contrast to acute GVHD, the pathophysiology of chronic GVHD remains poorly understood, and it is treated with a variety of immunosuppressive agents. The response of chronic GVHD to treatment is unpredictable, and mixed responses in different organs can occur in the same patient. Confounding variables such as infection and co-morbidities also make responses hard to measure. The use of corticosteroids (with or without a calcineurin inhibitor) is the standard of care, but a randomized trial of more than 300 patients with chronic GVHD found no difference between cyclosporine plus prednisone versus prednisone alone. ${ }^{132}$ Chronic immunosuppressants, especially those containing steroids, are highly toxic and result in infectious deaths. Many second line therapies have been studied, but none has achieved widespread acceptance. As mentioned above, ECP shows some promise, with significant response rates in high-risk patients. The best responses were observed in skin, liver, oral mucosa, eye, and lung.133 This observation is particularly relevant because lung GVHD has the potential to be a particularly devastating complication necessitating lung transplant as the only therapeutic option.134, 135

Essential Supportive Care in GVHD Patients: Meticulous supportive care is critical for patients with both acute and chronic GVHD because of the extended duration of immunosuppressive treatments and because the multiple medications required may have synergistic toxicities. Such care includes extensive infectious prophylaxis, early interventions in cases of suspected infections, and prophylaxis against non-infectious side effects of medications (See Table 3). These complications often require rapid responses to prevent serious or irreversible damage, and are best handled in close collaboration between the primary physician and the transplant specialist.

All patients should receive at least fluconazole as prophylaxis against fungal infections. Invasive molds, especially aspergillus, are common in patients with prolonged steroid use. 136 Prophylaxis with voriconazole or posaconazole should be considered for these patients. Usual sites of infection are the lungs, sinuses, brain, skin,137 and serial galactomannan assays may aid in the early detection. ${ }^{138}$ Candida can cause lesions in the lung and spleen, which may need screening with ultrasonography. Pneumocystis is another opportunistic infection that should receive cotrimoxazol (bactrim) prophylaxis. ${ }^{139}$ 
Viral infections are frequent in these patients with GVHD. Cytomegalovirus causes interstitial pneumonia and gastritis. Patients who are at risk should have their blood monitored several times monthly. Techniques that directly detect virus should be performed, such as CMV PCR or pp65 antigen, and evidence of increased viral load should prompt preemptive treatment with ganciclovir or foscarnet prior to clinical manifestations of disease. Shingles is not uncommon and acyclovir prophylaxis may be beneficial. ${ }^{140}$ Patients and caregivers should receive vaccinations against influenza, and treatment with neuraminidase inhibitors is recommended in the event of influenza infection. ${ }^{141,142}$

Patients with GVHD often have $\mathrm{IgG}_{2}$ and $\mathrm{IgG}_{4}$ subclass deficiencies despite normal $\operatorname{lgG}$ levels, making them susceptible to infections with encapsulated organisms. Treatment of severe hypogammaglobulinemia with intravenous immunoglobulin is standard in many centers, 143 but the level that triggers replacement varies considerably among transplant specialists. There is little supporting evidence for the routine use of intravenous immunoglobulin as prophylaxis ${ }^{144}$ but patients should receive routine prophylaxis (penicillin or its equivalent) due to the increased risk of streptococcal sepsis. ${ }^{145}$ Pneumococcal conjugate and hemophilus influenza vaccine may provide additional protection and are also recommended for all patients, including those with chronic GVHD. 139, 146, 147 The sites of any indwelling catheters should be assessed regularly and early treatment of a suspected infection initiated. Early signs or symptoms of septic shock such as shaking chills or low blood pressure requires prompt evaluation with chest X-ray and/or CT scan, blood culture and broad spectrum antibiotics because shock may progress rapidly in these patients.

Chronic immunosuppressant therapy has multiple toxicities. Diabetes (which further increases the risks of infection), muscle weakness, osteoporosis, avascular necrosis (often requiring joint replacement) and other Cushingoid features are common with chronic steroid use. Frequent monitoring of blood glucose and screening bone density is recommended, and treatment includes insulin, calcium, Vitamin D and bisphosphonates. ${ }^{148,} 149$ Calcineurin inhibitors frequently cause renal impairment, hypertension, and neurologic paraesthesias. Standard supportive care includes blood pressure monitoring, assessment of renal function, and monitoring of drug blood levels, which should be maintained within therapeutic parameters. To prevent renal dysfunction, most centers recommend vigorous oral outpatient hydration. Some patients will be unable to tolerate calcineurin inhibitors and will require different immunosuppressive medications altogether. Cytopenias sometimes require treatment with growth factors such as G-CSF or cessation of the offending agent. These maneuvers should always be performed in close consultation with a transplant specialist.

Future Directions: As allogeneic transplantation becomes an increasingly attractive therapeutic option, the need for novel approaches to GVHD has accelerated. The number of patients receiving transplants from unrelated donors is expected to double in the next five years, significantly increasing the population of patients with GVHD. The advent of RIC regimens has reduced transplant-related mortality and lengthened the period during which acute GVHD may develop (many new cases present up to day 200) and the need for close monitoring of patients in this period has increased. Patients have often returned to the care of their primary hematologists by this time, increasing the need for these physicians to collaborate with transplant specialists in the management of GVHD and its complications. Identification of biomarkers for GVHD with diagnostic (and possibly prognostic) significance may eventually make the treatment of GVHD preemptive rather than prophylactic. The use of cellular component therapy, such as regulatory $\mathrm{T}$ cells that have been expanded ex vivo. will also enter clinical trials in the near future, but the extensive infrastructure required for such cellular approaches will likely limit their use initially to 
large academic centers, intensifying the need for close communication between transplant specialists and referring hematologists.

Search Strategy and Selection Criteria: Pubmed and Medline databases were searched using the search term GVHD that was thencross-referenced with each of the following words: clinical, cytokines, MHC and HLA antigens, biology and immunology. The criteria used to include mostly the peer-reviewed original and review journal articles published within the last decade except for those seminal articles that initially described the clinical features. All non-peer reviewed manuscripts, supplements and textbooks were excluded.

\section{Acknowledgments}

This work was supported in part by grants from the National Institutes of Health (Bethesda, MD), P01 CA 39542, and the Jose Carreras Foundation. James L.M. Ferrara, M. D. is a Doris Duke Distinguished Clinical Scientist and an American Cancer Society Professor.

\section{References}

1. Appelbaum FR. Haematopoietic cell transplantation as immunotherapy. Nature 2001;411:385-389. [PubMed: 11357147]

2. Welniak LA, Blazar BR, Murphy WJ. Immunobiology of allogeneic hematopoietic stem cell transplantation. Annu Rev Immunol 2007;25:139-170. [PubMed: 17129175]

3. Billingham RE. The biology of graft-versus-host reactions. Harvey Lect 1966-67;62:21-78. [PubMed: 4875305]

4. Korngold, R.; Sprent, J. Purified T cell subsets and lethal graft-versus-host disease in mice. In: Gale, RP.; Champlin, R., editors. Progress in Bone Marrow Transplantation. Alan R. Liss, Inc.; New York: 1987. p. 213-218.

5. Kernan NA, Collins NH, Juliano LL, Cartagena TT, Dupont BB, OReilly RJ. Clonable T lymphocytes in T cell-depleted bone marrow transplants correlate with development of graft-v-host disease. Blood 1986;68:770-773. [PubMed: 3527302]

6. Petersdorf EW, Longton GM, Anasetti C, et al. The significance of HLA-DRB1 matching on clinical outcome after HLA-A, B, DR identical unrelated donor marrow transplantation. Blood 1995;1995;86:1606-1613. [PubMed: 7632970]

7. Krensky AM, Weiss A, Crabtree G, Davis MM, Parham P. T-lymphocyte-antigen interactions in transplant rejection. N Engl J Med 1990;322:510-517. [PubMed: 2405272]

8. Loiseau P, Busson M, Balere ML, et al. HLA Association with hematopoietic stem cell transplantation outcome: the number of mismatches at HLA-A, -B, -C, -DRB1, or -DQB1 is strongly associated with overall survival. Biol Blood Marrow Transplant 2007;13:965-974. [PubMed: 17640601]

9. Ratanatharathorn V, Nash RA, Przepiorka D, et al. Phase III study comparing methotrexate and tacrolimus (prograf, FK506) with methotrexate and cyclosporine for graft-versus-host disease prophylaxis after HLA-identical sibling bone marrow transplantation. Blood 1998;92:2303-2314. [PubMed: 9746768]

10. Cornetta K, Laughlin M, Carter S, et al. Umbilical cord blood transplantation in adults: results of the prospective Cord Blood Transplantation (COBLT). Biol Blood Marrow Transplant 2005;11:149-160. [PubMed: 15682076]

11. Wagner JE, Barker JN, DeFor TE, et al. Transplantation of unrelated donor umbilical cord blood in 102 patients with malignant and nonmalignant diseases: influence of CD34 cell dose and HLA disparity on treatment-related mortality and survival. Blood 2002;100:1611-1618. [PubMed: 12176879]

12. Barker JN, Wagner JE. Umbilical-cord blood transplantation for the treatment of cancer. Nat Rev Cancer 2003;3:526-532. [PubMed: 12835672]

13. Bleakley MR, S. R. Molecules and mechanisms of the graft-versus-leukaemia effect. Nature Rev Cancer 2004;4:371-380. [PubMed: 15122208] 
14. Goulmy E, Schipper R, Pool J, et al. Mismatches of minor histocompatibility antigens between HLA-identical donors and recipients and the development of graft-versus-host disease after bone marrow transplantation. N Engl J Med 1996;334:281-285. [PubMed: 8532022]

15. Antin JH, Ferrara JL. Cytokine dysregulation and acute graft-versus-host disease. Blood 1992;80:2964. [PubMed: 1467511]

16. Cavet J, Middleton PG, Segall M, Noreen H, Davies SM, Dickinson AM. Recipient tumor necrosis factor-alpha and interleukin-10 gene polymorphisms associate with early mortality and acute graftversus-host disease severity in HLA-matched sibling bone marrow transplants. Blood 1999;94:3941-32946. [PubMed: 10572111]

17. Lin MT, Storer B, Martin PJ, et al. Relation of an interleukin-10 promoter polymorphism to graftversus-host disease and survival after hematopoietic-cell transplantation. N Engl J Med 2003;349:2201-2210. [PubMed: 14657427]

18. Dickinson AM, Charron D. Non-HLA immunogenetics in hematopoietic stem cell transplantation. Curr Opin Immunol 2005;17:517-525. [PubMed: 16085403]

19. Miller JS, Soignier Y, Panoskaltsis-Mortari A, et al. Successful adoptive transfer and in vivo expansion of human haploidentical NK cells in patients with cancer. Blood 2005;105:3051-3057. [PubMed: 15632206]

20. Miller JS, Cooley S, Parham P, et al. Missing KIR ligands are associated with less relapse and increased graft-versus-host disease (GVHD) following unrelated donor allogeneic HCT. Blood 2007;109:5058-5061. [PubMed: 17317850]

21. Velardi A, Ruggeri L, Alessandro L, Moretta, Moretta. NK cells: a lesson from mismatched hematopoietic transplantation. Trends Immunology 2002;23:438-444.

22. Holler E, Rogler G, Brenmoehl J, et al. Prognostic significance of NOD2/CARD15 variants in HLA-identical sibling hematopoietic stem cell transplantation: effect on long-term outcome is confirmed in 2 independent cohorts and may be modulated by the type of gastrointestinal decontamination. Blood 2006;107:4189-4193. [PubMed: 16424393]

23. Martin PJ, Schoch G, Fisher L, et al. A retrospective analysis of therapy for acute graft-versus-host disease: initial treatment. Blood 1990;76:1464-1472. [PubMed: 2207321]

24. Sullivan KM, Agura E, Anasetti C, et al. Chronic graft-versus-host disease and other late complications of bone marrow transplantation. Semin Hemat 1991;28:250-259. [PubMed: 1887253]

25. Sullivan KM, Mori M, Sanders J, et al. Late complications of allogeneic and autologous marrow transplantation. Bone Marrow Transplant 1992;10:127-134. [PubMed: 1521083]

26. Filipovich AH, Weisdorf D, Pavletic S, et al. National Institutes of Health consensus development project on criteria for clinical trials in chronic graft-versus-host disease: I. Diagnosis and staging working group report. Biol Blood Marrow Transplant 2005;11:945-956. [PubMed: 16338616]

27. Vogelsang GB, Lee L, Bensen-Kennedy DM. Pathogenesis and treatment of graft-versus-host disease after bone marrow transplant. Annu Rev Med 2003;54:29-52. [PubMed: 12359826]

28. Cooke KR, Kobzik LL, Martin TR, et al. An experimental model of idiopathic pneumonia syndrome after bone marrow transplantation: I. The roles of minor $\mathrm{H}$ antigens and endotoxin. Blood 1996;88:3230-9. [PubMed: 8963063]

29. Ferrara JL, Deeg HJ. Graft-versus-host disease. N Engl J Med 1991;324:667-674. [PubMed: 1994250]

30. Goker H, Haznedaroglu IC, Chao NJ. Acute graft-vs-host disease: pathobiology and management. Exp Hematol 2001;29:259-277. [PubMed: 11274753]

31. Nevo S, Enger C, Swan V, et al. Acute bleeding after allogeneic bone marrow transplantation: association with graft versus host disease and effect on survival. Transplant 1999;67:681-689.

32. Ponec RJ, Hackman RC, McDonald GB. Endoscopic and histologic diagnosis of intestinal graftversus-host disease after marrow transplantation. Gastrointest Endosc 1999;49:612-621. [PubMed: 10228260]

33. Snover DC, Weisdorf SA, Vercellotti GM, Rank B, Hutton S, McGlave P. A histopathologic study of gastric and small intestinal graft-versus-host disease following allogeneic bone marrow transplantation. Hum Pathol 1985;16:387-392. [PubMed: 3884482] 
34. Snover DC, Weisdorf SA, Ramsay NK, McGlave P, Kersey JH. Hepatic graft versus host disease: a study of the predictive value of liver biopsy in diagnosis. Hepatology 1984;4:123-130. [PubMed: 6363248]

35. Fujii N, Takenaka K, Shinagawa K, et al. Hepatic graft-versus-host disease presenting as an acute hepatitis after allogeneic peripheral blood stem cell transplantation. Bone Marrow Transplant 2001;27:1007-1010. [PubMed: 11436113]

36. Cahn JY, Klein JP, Lee SJ, et al. Prospective evaluation of 2 acute graft-versus-host (GVHD) grading systems: a joint Societe Francaise de Greffe de Moelle et Therapie Cellulaire (SFGM-TC), Dana Farber Cancer Institute (DFCI), and International Bone Marrow Transplant Registry (IBMTR) prospective study. Blood 2005;106:1495-1500. [PubMed: 15878974]

37. Anasetti C, Rybka W, Sullivan KM, Banaji M, Slichter SJ. Graft-v-host disease is associated with autoimmune-like thrombocytopenia. Blood 1989;73:1054-1058. [PubMed: 2920206]

38. Petersdorf EW, Longton G, Anasetti C, et al. Donor-recipient disparities for HLAC genes is a risk factor for graft failure following marrow transplantation from unrelated donors. Blood 1995;86:1606-1613. [PubMed: 7632970]

39. Flomenberg N, Baxter-Lowe LA, Confer D, Fernandez-Vina M, et al. Impact of HLA class I and class II high-resolution matching on outcomes of unrelated donor bone marrow transplantation: HLA-C mismatching is associated with a strong adverse effect on transplantation outcome. Blood 2004;104:1923-1930. [PubMed: 15191952]

40. Lee SJ, Klein JP, Barrett AJ, et al. Severity of chronic graft-versus-host disease: association with treatment-related mortality and relapse. Blood 2002;100:406-414. [PubMed: 12091329]

41. Carlens S, Ringden O, Remberger M, Lonnqvist B, Hagglund H, Klaesson S, et al. Risk factors for chronic graft-versus-host disease after bone marrow transplantation: a retrospective single centre analysis. Bone Marrow Transplant 1998;22:755-761. [PubMed: 9827972]

42. Matzinger P. The danger model: a renewed sense of self. Science 2002;296:301-305. [PubMed: 11951032]

43. Shlomchik WD, Couzens MS, Tang CB, et al. Prevention of graft versus host disease by inactivation of host antigen-presenting cells. Science 1999;285:412-415. [PubMed: 10411505]

44. Teshima T, Ordemann R, Reddy P, et al. Acute graft-versus-host disease does not require alloantigen expression on host epithelium. Nat Med 2002;8:575-581. [PubMed: 12042807]

45. Reddy P, Maeda Y, Liu C, Krijanovski OI, Korngold R, Ferrara JL. A crucial role for antigenpresenting cells and alloantigen expression in graft-versus-leukemia responses. Nat Med 2005;11:1244-1249. [PubMed: 16227991]

46. Kolb HJ, Holler E. Adoptive immunotherapy with donor lymphocyte transfusions. Curr Opin Oncol 1997;9:139-145. [PubMed: 9161791]

47. Storb R, Rudolph RH, Thomas ED. Marrow grafts between canine siblings matched by serotyping and mixed leukocyte culture. J Clin Invest 1971;50:1272-1275. [PubMed: 4931083]

48. Xun CQ, Thompson JS, Jennings CD, Brown SA, Widmer MB. Effect of total body irradiation, busulfan-cyclophosphamide, or cyclophosphamide conditioning on inflammatory cytokine release and development of acute and chronic graft-versus-host disease in H-2-incompatible transplanted SCID mice. Blood 1994;83:2360-2367. [PubMed: 8161803]

49. Hill GR, Ferrara JL. The primacy of the gastrointestinal tract as a target organ of acute graftversus-host disease: rationale for the use of cytokine shields in allogeneic bone marrow transplantation. Blood 2000;95:2754-2759. [PubMed: 10779417]

50. Hill GR, Crawford JM, Cooke KR, Brinson YS, Pan L, Ferrara JL. Total body irradiation and acute graft-versus-host disease: the role of gastrointestinal damage and inflammatory cytokines. Blood 1997;90:3204-3213. [PubMed: 9376604]

51. Choi SW, Kitko CL, Braun T, et al. Change plasma tumor necrosis factor recept-1 levels in the first week post-myeloablative allogeneic transplant correlated with severity and incidence of GVHD and survival. Blood. (In Press).

52. Murai M, Yoneyama H, Ezaki T, et al. Peyer's patch is the essential site in initiating murine acute and lethal graft-versus-host reaction. Nat Immunol 2003;4:154-160. [PubMed: 12524535]

53. Duffner UA, Maeda Y, Cooke KR, et al. Host dendritic cells alone are sufficient to initiate acute graft-versus-host disease. J Immunol 2004;172:7393-7398. [PubMed: 15187116] 
54. Sato K, Yamashita N, Baba M, Matsuyama T. Regulatory dendritic cells protect mice from murine acute graft-versus-host disease and leukemia relapse. Immunity 2003;18:367-379. [PubMed: 12648454]

55. Medzhitov R, Janeway CA Jr. Decoding the patterns of self and nonself by the innate immune system. Science 2002;296:298-300. [PubMed: 11951031]

56. Cooke KR, Gerbitz A, Crawford JM, et al. LPS antagonism reduces graft-versus-host disease and preserves graft-versus-leukemia activity after experimental bone marrow transplantation. J Clin Invest 2001;107:1581-1589. [PubMed: 11413166]

57. Akira S, Uematsu S, Takeuchi O. Pathogen recognition and innate immunity. Cell 2006;124:783801. [PubMed: 16497588]

58. Dustin ML. Role of adhesion molecules in activation signaling in T lymphocytes. J Clin Immunol 2001;21:258-263. [PubMed: 11506195]

59. Csencsits KL, Bishop DK. Contrasting alloreactive CD4+ and CD8+ T cells: there's more to it than MHC restriction. Am J Transplant 2003;3:107-115. [PubMed: 12603205]

60. Korngold R, Sprent J. Features of T cells causing H-2-restricted lethal graft-vs.-host disease across minor histocompatibility barriers. J Exp Med 1982;155:872-883. [PubMed: 6977610]

61. Korngold R, Sprent J. Surface markers of T cells causing lethal graft-vs-host disease to class I vs class II H-2 differences. J Immunol 1985;135:3004-3010. [PubMed: 3876371]

62. Cohen JL, Boyer O. The role of CD4+CD25hi regulatory T cells in the physiopathogeny of graftversus-host disease. Curr Opin Immunol 2006;18:580-585. [PubMed: 16879951]

63. Zeng D, Lewis D, Dejbakhsh-Jones S, et al. Bone marrow NK1.1(-) and NK1.1(+) T cells reciprocally regulate acute graft versus host disease. J Exp Med 1999;189:1073-1081. [PubMed: 10190898]

64. Zeng D, Dejbakhsh-Jones S, Strober S. Granulocyte Colony-Stimulating Factor Reduces the Capacity of Blood Mononuclear Cells to Induce Graft-Versus-Host Disease: Impact on Blood Progenitor Cell Transplantation. Blood 1997;90:453-463. [PubMed: 9207483]

65. Lowsky R, Takahashi T, Liu YP, et al. Protective conditioning for acute graft-versus-host disease. N Engl J Med 2005;353:1321-1331. [PubMed: 16192477]

66. Morris ES, MacDonald KP, Rowe V, et al. NKT cell-dependent leukemia eradication following stem cell mobilization with potent G-CSF analogs. J Clin Invest 2005;115:3093-3103. [PubMed: 16224535]

67. Zeiser R, Nguyen VH, Beilhack A, et al. Inhibition of CD4+CD25+ regulatory T-cell function by calcineurin-dependent interleukin-2 production. Blood 2006;108:390-399. [PubMed: 16522809]

68. Fowler DH, Kurasawa K, Smith R, Eckhaus MA, Gress RE. Donor CD4-enriched cells of Th2 cytokine phenotype regulate graft-versus-host disease without impairing allogeneic engraftment in sublethally irradiated mice. Blood 1994;84:3540-3549. [PubMed: 7949109]

69. Yang YG, Dey BR, Sergio JJ, Pearson DA, Sykes M. Donor-derived interferon gamma is required for inhibition of acute graft-versus-host disease by interleukin 12. J Clin Invest 1998;102:21262135. [PubMed: 9854048]

70. Ferrara, JLM. Graft-versus-host disease. W.B. Saunders Company; Philadelphia: 2006.

71. Ferrara JL, Reddy P. Pathophysiology of graft-versus-host disease. Semin Hematol 2006;43:3-10. [PubMed: 16412784]

72. Krenger W, Falzarano G, Delmonte J Jr. Snyder KM, Byon JC, Ferrara JL. Interferon-gamma suppresses T-cell proliferation to mitogen via the nitric oxide pathway during experimental acute graft-versus-host disease. Blood 1996;88:1113-1121. [PubMed: 8704222]

73. Reddy P, Teshima T, Kukuruga M, et al. Interleukin-18 regulates acute graft-versus-host disease by enhancing Fas-mediated donor T cell apoptosis. J Exp Med 2001;194:1433-1440. [PubMed: 11714750]

74. Banovic T, MacDonald KP, Morris ES, et al. TGF-beta in allogeneic stem cell transplantation: friend or foe? Blood 2005;106:2206-2214. [PubMed: 15941908]

75. van den Brink MR, Burakoff SJ. Cytolytic pathways in haematopoietic stem-cell transplantation. Nat Rev Immunol 2002;2:273-281. [PubMed: 12001998] 
76. Wysocki CA, Panoskaltsis-Mortari A, Blazar BR, Serody JS. Leukocyte migration and graftversus-host disease. Blood 2005;105:4191-4199. [PubMed: 15701715]

77. Waldman E, Lu SX, Hubbard VM, et al. Absence of beta7 integrin results in less graft-versus-host disease because of decreased homing of alloreactive T cells to intestine. Blood 2006;107:17031711. [PubMed: 16291587]

78. Welniak LA, Kuprash DV, Tumanov AV, et al. Peyer's patches are not required for acute graftversus-host disease after myeloablative conditioning and murine allogeneic bone marrow transplantation. Blood 2005;107:410-412. [PubMed: 16160014]

79. Iwasaki A, Medzhitov R. Toll-like receptor control of the adaptive immune responses. Nat Immunol 2004;5:987-995. [PubMed: 15454922]

80. Hill GR, Teshima T, Rebel VI, et al. The p55 TNF-alpha receptor plays a critical role in T cell alloreactivity. J Immunol 2000;164:656-663. [PubMed: 10623807]

81. Piguet PF, Grau GE, Allet B, Vassalli P. Tumor necrosis factor/cachectin is an effector of skin and gut lesions of the acute phase of graft-vs.-host disease. J Exp Med 1987;166:1280-1289. [PubMed: 3316469]

82. Brown GR, Lee E, Thiele DL. TNF-TNFR2 interactions are critical for the development of intestinal graft-versus-host disease in MHC class II-disparate (C57BL/6J-->C57BL/6J x bm12)F1 mice. J Immunol 2002;168:3065-3071. [PubMed: 11884480]

83. Soiffer, R. T-Cell Depletion to Prevent Graft-vs-host Disease. 3 ed.. Blackwell; Carlton: 2008.

84. Marmont AM, Horowitz M, Gale RP, et al. T-cell depletion of HLA-identical transplants in leukemia. Blood 1991;78:2120-2130. [PubMed: 1912589]

85. O'Reilly RJ, Brochstein JA, Collins NH, et al. Evaluation of HLA-haplotype disparate parental marrow grafts depleted of $\mathrm{T}$ lymphocytes by differential agglutination with a soybean lectin and Erosette depletion for the treatment of severe combined immunodeficiency. Vox Sang 1986;51:8186. [PubMed: 3532540]

86. Platzbecker U, Ehninger G, Bornhäuser M. Allogeneic transplantation of CD34+ selected hematopoietic cells--clinical problems and current challenges. Leukemia \& Lymphoma 2004;45:447-453. [PubMed: 15160905]

87. Urbano-Ispizua A, Rozman C, Martínez C, et al. Rapid engraftment without significant graftversus-host disease after allogeneic transplantation of CD34+ selected cells from peripheral blood. Blood 1997;89:3967-3973. [PubMed: 9166834]

88. Wagner JE, Thompson JS, Carter SL, Kernan NA. Effect of graft-versus-host disease prophylaxis on 3-year disease-free survival in recipients of unrelated donor bone marrow (T-cell Depletion Trial): a multi-centre, randomised phase IIIII trial. Lancet 2005;366:733-741. [PubMed: 16125590]

89. Ash RC, Casper JT, Chitambar CR, et al. Successful allogeneic transplantation of T-cell-depleted bone marrow from closely HLA-matched unrelated donors. N Engl J Med 1990;322:485-494. [PubMed: 2300120]

90. Bacigalupo AA, Lamparelli TT, Bruzzi PP, et al. Antithymocyte globulin for graft-versus-host disease prophylaxis in transplants from unrelated donors: 2 randomized studies from Gruppo Italiano Trapianti Midollo Osseo (GITMO). Blood 2001;98:2942-2947. [PubMed: 11698275]

91. Barge RMY, Starrenburg CWJ, Falkenburg JHF, Fibbe WE, Marijt EW, Willemze RR. Long-term follow-up of myeloablative allogeneic stem cell transplantation using Campath "in the bag" as Tcell depletion: the Leiden experience. Bone Marrow Transplant 2006;37:1129-1134. [PubMed: 16757974]

92. Martin PJ, Hansen JA, Torok-Storb B, et al. Effects of treating marrow with a CD3-specific immunotoxin for prevention of acute graft-versus-host disease. Bone Marrow Transplant 1988;3:437-44. [PubMed: 2973360]

93. Ringdén O, Remberger M, Aschan J, Lungman P, Lönnqvist B, Markling L. Long-term follow-up of a randomized trial comparing $\mathrm{T}$ cell depletion with a combination of methotrexate and cyclosporine in adult leukemic marrow transplant recipients. Transplantation 1994;58:887-891. [PubMed: 7940731] 
94. Champlin RE, Passweg JR, Zhang MJ, et al. T-cell depletion of bone marrow transplants for leukemia from donors other than HLA-identical siblings: advantage of T-cell antibodies with narrow specificities. Blood 2000;95:3996-4003. [PubMed: 10845940]

95. Chalandon Y, Roosnek E, Mermillod B, Waelchli L, Helg C, Chapuis B. Can only partial T-cell depletion of the graft before hematopoietic stem cell transplantation mitigate graft-versus-host disease while preserving a graft-versus-leukemia reaction? A prospective phase II study. Biol Blood Marrow Transplant 2006;12:102-110. [PubMed: 16399574]

96. Goerner M, Weber-Nordt R, Hoepfner S, Benner A, Luft T, Ho AD. Addition of a low fixed number of CD3+ cells to CD34-enriched allografts: effects on engraftment, graft-versus-host disease, and survival after related and unrelated peripheral stem cell transplantation. $\mathbf{J}$ Hematotherapy \& stem cell research 2003;12:309-320.

97. Ho VT, Kim HT, Li S, et al. Partial CD8+ T-cell depletion of allogeneic peripheral blood stem cell transplantation is insufficient to prevent graft-versus-host disease. Bone Marrow Transplant 2004;34:987-994. [PubMed: 15489873]

98. Perez-Simon JA, Diez-Campelo M, Martino R, et al. Influence of the intensity of the conditioning regimen on the characteristics of acute and chronic graft-versus-host disease after allogeneic transplantation. Br J Haematol 2005; 130:394-403. [PubMed: 16042689]

99. Perez-Simon JA, Kottaridis PD, Martino R, et al. Nonmyeloablative transplantation with or without alemtuzumab: comparison between 2 prospective studies in patients with lymphoproliferative disorders. Blood 2002;100:3121-3127. [PubMed: 12384408]

100. Delgado J, Thomson K, Russell N, et al. Results of alemtuzumab-based reduced-intensity allogeneic transplantation for chronic lymphocytic leukemia: a British Society of Blood and Marrow Transplantation Study. Blood 2006;107:1724-1730. [PubMed: 16239425]

101. Guinan EC, Boussiotis VA, Neuberg D, et al. Transplantation of anergic histoincompatible bone marrow allografts. N Engl J Med 1999;340:1704-1714. [PubMed: 10352162]

102. Bacigalupo A. Antilymphocyte/thymocyte globulin for graft versus host disease prophylaxis: efficacy and side effects. Bone Marrow Transplant 2005;35:225-231. [PubMed: 15558041]

103. Kroger N, Zabelina T, Kruger W, et al. In vivo T cell depletion with pretransplant anti-thymocyte globulin reduces graft-versus-host disease without increasing relapse in good risk myeloid leukemia patients after stem cell transplantation from matched related donors. Bone Marrow Transplant 2002;29:683-689. [PubMed: 12180114]

104. Remberger M, Mattsson J, Ringden O. Polyclonal anti-T-cell globulin as part of the preparative regimen for pediatric allogeneic stem-cell transplantation. Pediatric Transplantation 2001;5:28592. [PubMed: 11472608]

105. Bacigalupo A, Lamparelli T, Bruzzi P, et al. Antithymocyte globulin for graft-versus-host disease prophylaxis in transplants from unrelated donors: 2 randomized studies from Gruppo Italiano Trapianti Midollo Osseo (GITMO). Blood 2001;98:2942-2947. [PubMed: 11698275]

106. Bacigalupo A, Lamparelli T, Barisione G, et al. Thymoglobulin prevents chronic graft-versushost disease, chronic lung dysfunction, and late transplant-related mortality: long-term follow-up of a randomized trial in patients undergoing unrelated donor transplantation. Biol Blood Marrow Transplant 2006;12:560-5. [PubMed: 16635791]

107. Nash RA, Antin JH, Karanes C, et al. Phase 3 study comparing methotrexate and tacrolimus with methotrexate and cyclosporine for prophylaxis of acute graft-versus-host disease after marrow transplantation from unrelated donors. Blood 2000;96:2062-8. [PubMed: 10979948]

108. Qu L, Kiss JE. Thrombotic microangiopathy in transplantation and malignancy. Semin Thromb Hemost 2005;31:691-699. [PubMed: 16388420]

109. Wong R, Beguelin GZ, de Lima M, et al. Tacrolimus-associated posterior reversible encephalopathy syndrome after allogeneic haematopoietic stem cell transplantation. $\mathrm{Br} \mathrm{J}$ Haematol 2003;122:128-34. [PubMed: 12823354]

110. Bolwell B, Sobecks R, Pohlman B, et al. A prospective randomized trial comparing cyclosporine and short course methotrexate with cyclosporine and mycophenolate mofetil for GVHD prophylaxis in myeloablative allogeneic bone marrow transplantation. Bone Marrow Transplant 2004;34:621-5. [PubMed: 15300236] 
111. Barker JN, Weisdorf DJ, DeFor TE, Blazar BR, Miller JS, Wagner JE. Rapid and complete donor chimerism in adult recipients of unrelated donor umbilical cord blood transplantation after reduced-intensity conditioning. Blood 2003;102:1915-9. [PubMed: 12738676]

112. Baron F, Baker JE, Storb R, et al. Kinetics of engraftment in patients with hematologic malignancies given allogeneic hematopoietic cell transplantation after nonmyeloablative conditioning. Blood 2004;104:2254-62. [PubMed: 15226174]

113. Burroughs L, Mielcarek M, Leisenring W, et al. Extending postgrafting cyclosporine decreases the risk of severe graft-versus-host disease after nonmyeloablative hematopoietic cell transplantation. Transplantation 2006;81:818-25. [PubMed: 16570002]

114. Cutler C, Kim HT, Hochberg E, et al. Sirolimus and tacrolimus without methotrexate as graftversus-host disease prophylaxis after matched related donor peripheral blood stem cell transplantation. Biol Blood Marrow Transplant 2004;10:328-36. [PubMed: 15111932]

115. Cutler C, Henry NL, Magee C, et al. Sirolimus and thrombotic microangiopathy after allogeneic hematopoietic stem cell transplantation. Biol Blood Marrow Transplant 2005;11:551-557. [PubMed: 15983555]

116. Mielcarek M, Martin PJ, Leisenring W, et al. Graft-versus-host disease after nonmyeloablative versus conventional hematopoietic stem cell transplantation. Blood 2003;102:756-62. [PubMed: 12663454]

117. Levine JE, Uberti JP, Ayash L, et al. Lowered-intensity preparative regimen for allogeneic stem cell transplantation delays acute graft-versus-host disease but does not improve outcome for advanced hematologic malignancy. Biol Blood Marrow Transplant 2003;9:189-97. [PubMed: 12652470]

118. Diaconescu R, Flowers CR, Storer B, et al. Morbidity and mortality with nonmyeloablative compared with myeloablative conditioning before hematopoietic cell transplantation from HLAmatched related donors. Blood 2004;104:1550-8. [PubMed: 15150081]

119. Martino R, Iacobelli S, Brand R, et al. Retrospective comparison of reduced-intensity conditioning and conventional high-dose conditioning for allogeneic hematopoietic stem cell transplantation using HLA-identical sibling donors in myelodysplastic syndromes. Blood 2006;108:836-46. [PubMed: 16597592]

120. Maris M, Storb R. The transplantation of hematopoietic stem cells after nonmyeloablative conditioning: a cellular therapeutic approach to hematologic and genetic diseases. Immunol Res 2003;28:13-24. [PubMed: 12947221]

121. MacMillan ML, Weisdorf DJ, Davies SM, et al. Early antithymocyte globulin therapy improves survival in patients with steroid-resistant acute graft-versus-host disease. Biol Blood Marrow Transplant 2002;8:40-6. [PubMed: 11858189]

122. MacMillan ML, Weisdorf DJ, Wagner JE, et al. Response of 443 patients to steroids as primary therapy for acute graft-versus-host disease: comparison of grading systems. Biol Blood Marrow Transplant 2002;8:387-94. [PubMed: 12171485]

123. Martin PJ, Schoch G, Fisher L, et al. A retrospective analysis of therapy for acute graft-versushost disease: secondary treatment. Blood 1991;77:1821-8. [PubMed: 2015405]

124. Cragg L, Blazar BR, Defor T, et al. A randomized trial comparing prednisone with antithymocyte globulin/prednisone as an initial systemic therapy for moderately severe acute graft-versus-host disease. Biol Blood Marrow Transplant 2000;6:441-7. [PubMed: 10975513]

125. McCaul KG, Nevill TJ, Barnett MJ, et al. Treatment of steroid-resistant acute graft-versus-host disease with rabbit antithymocyte globulin. J Hematother Stem Cell Res 2000;9:367-74. [PubMed: 10894358]

126. Arai S, Margolis J, Zahurak M, Anders V, Vogelsang GB. Poor outcome in steroid-refractory graft-versus-host disease with antithymocyte globulin treatment. Biol Blood Marrow Transplant 2002;8:155-60. [PubMed: 11939605]

127. Barr ML, Meiser BM, Eisen HJ, et al. Photopheresis for the prevention of rejection in cardiac transplantation. Photopheresis Transplantation Study Group. N Engl J Med 1998;339:1744-1751. [PubMed: 9845709] 
128. Gatza E, Rogers CE, Clouthier SG, et al. Extracorporeal photopheresis reverses experimental graft-versus-host disease through regulatory T cells. Blood. 2008 prepublished online April 14. DOI:10.1182/blood-2007-11-125542.

129. Greinix HT, Knobler RM, Worel N, et al. The effect of intensified extracorporeal photochemotherapy on long-term survival in patients with severe acute graft-versus-host disease. Haematologica 2006;91:405-8. [PubMed: 16531267]

130. Reddy P, Ferrara JL. Immunobiology of acute graft-versus-host disease. Blood Rev 2003;17:18794. [PubMed: 14556773]

131. Levine JE, Paczesny S, Mineishi S, et al. Etanercept plus methylprednisolone as initial therapy for acute graft-versus-host disease. Blood 2008;111:2470-5. [PubMed: 18042798]

132. Koc S, Leisenring W, Flowers ME, et al. Therapy for chronic graft-versus-host disease: a randomized trial comparing cyclosporine plus prednisone versus prednisone alone. Blood 2002;100:48-51. [PubMed: 12070007]

133. Couriel D, Hosing C, Saliba R, et al. Extracorporeal photopheresis for acute and chronic graftversus-host disease: does it work? Biol Blood Marrow Transplant 2006;12:37-40. [PubMed: 16399600]

134. Sano Y, Date H, Nagahiro I, Aoe M, Shimizu N. Living-Donor Lobar Lung Transplantation for Bronchiolitis Obliterans After Bone Marrow Transplantation. Annals Thoracic Surgery 2005;79:1051-1052.

135. Rabitsch W, Deviatko E, Keil F, et al. Successful lung transplantation for bronchiolitis obliterans after allogeneic marrow transplantation. Transplant 2001;71:1341-1343.

136. Marr KA, Carter RA, Boeckh M, Martin P, Corey L. Invasive aspergillosis in allogeneic stem cell transplant recipients: changes in epidemiology and risk factors. Blood 2002;100:4358-4366. [PubMed: 12393425]

137. Baddley J, Stroud T, Salzman D, Pappas P. Invasive Mold Infections in Allogeneic Bone Marrow Transplant Recipients. Clin Infect Diseases 2001;32:1319-1324. [PubMed: 11303267]

138. Rovira M, Jimenez M, De La Bellacasa J, et al. Detection of Aspergillus galactomannan by enzyme immunoabsorbent assay in recipients of allogeneic hematopoietic stem cell transplantation: a prospective study. Transplant 2004;77:1260-4.

139. Guidelines for preventing opportunistic infections among hematopoietic stem cell transplant recipients. Biol Blood Marrow Transplant 2000;6:659-713. [PubMed: 11185897]

140. Boeckh M, Kim HW, Flowers ME, Meyers JD, Bowden RA. Long-term acyclovir for prevention of varicella zoster virus disease after allogeneic hematopoietic cell transplantation--a randomized double-blind placebo-controlled study. Blood 2006;107:1800-1805. [PubMed: 16282339]

141. Machado CM, Cardoso MRA, da Rocha IF, Boas LSV, Dulley FL, Pannuti CS. The benefit of influenza vaccination after bone marrow transplantation. Bone Marrow Transplant 2005;36:897900. [PubMed: 16170332]

142. Machado CM, Boas LSV, Mendes AVA, et al. Use of Oseltamivir to control influenza complications after bone marrow transplantation. Bone Marrow Transplant 2004;34:111-114. [PubMed: 15094755]

143. Darabi K, Abdel-Wahab O, Dzik WH. Current usage of intravenous immune globulin and the rationale behind it: the Massachusetts General Hospital data and a review of the literature. Transfusion 2006;46:741-53. [PubMed: 16686841]

144. Kumar A, Teuber SS, Gershwin ME. Intravenous immunoglobulin: striving for appropriate use. Int Arch Allergy Immunol 2006;140:185-98. [PubMed: 16682800]

145. Kulkarni S, Powles R, Treleaven J, et al. Chronic graft versus host disease is associated with long-term risk for pneumococcal infections in recipients of bone marrow transplants. Blood 2000;95:3683-6. [PubMed: 10845897]

146. Meisel R, Kuypers L, Dirksen U, et al. Pneumococcal conjugate vaccine provides early protective antibody responses in children after related and unrelated allogeneic hematopoietic stem cell transplantation. Blood 2007;109:2322-2326. [PubMed: 17090650]

147. Ljungman P, Engelhard D, de la Cámara R, et al. Vaccination of stem cell transplant recipients: recommendations of the Infectious Diseases Working Party of the EBMT. Bone Marrow Transplantation 2005;35:737-746. [PubMed: 15750612] 
148. Carpenter PA, Hoffmeister P, Chesnut CH III, et al. Bisphosphonate Therapy for Reduced Bone Mineral Density in Children with Chronic Graft-versus-Host Disease. Biol Blood Marrow Transplant 2007;13:683-690. [PubMed: 17531778]

149. Rizzo JD, Wingard JR, Tichelli A, et al. Recommended screening and preventive practices for long-term survivors after hematopoietic cell transplantation: joint recommendations of the European Group for Blood and Marrow Transplantation, Center for International Blood and Marrow Transplant Research, and the American Society for Blood and Marrow Transplantation (EBMT/CIBMTR/ASBMT). Bone Marrow Transplant 2006;37:249-261. [PubMed: 16435004] 


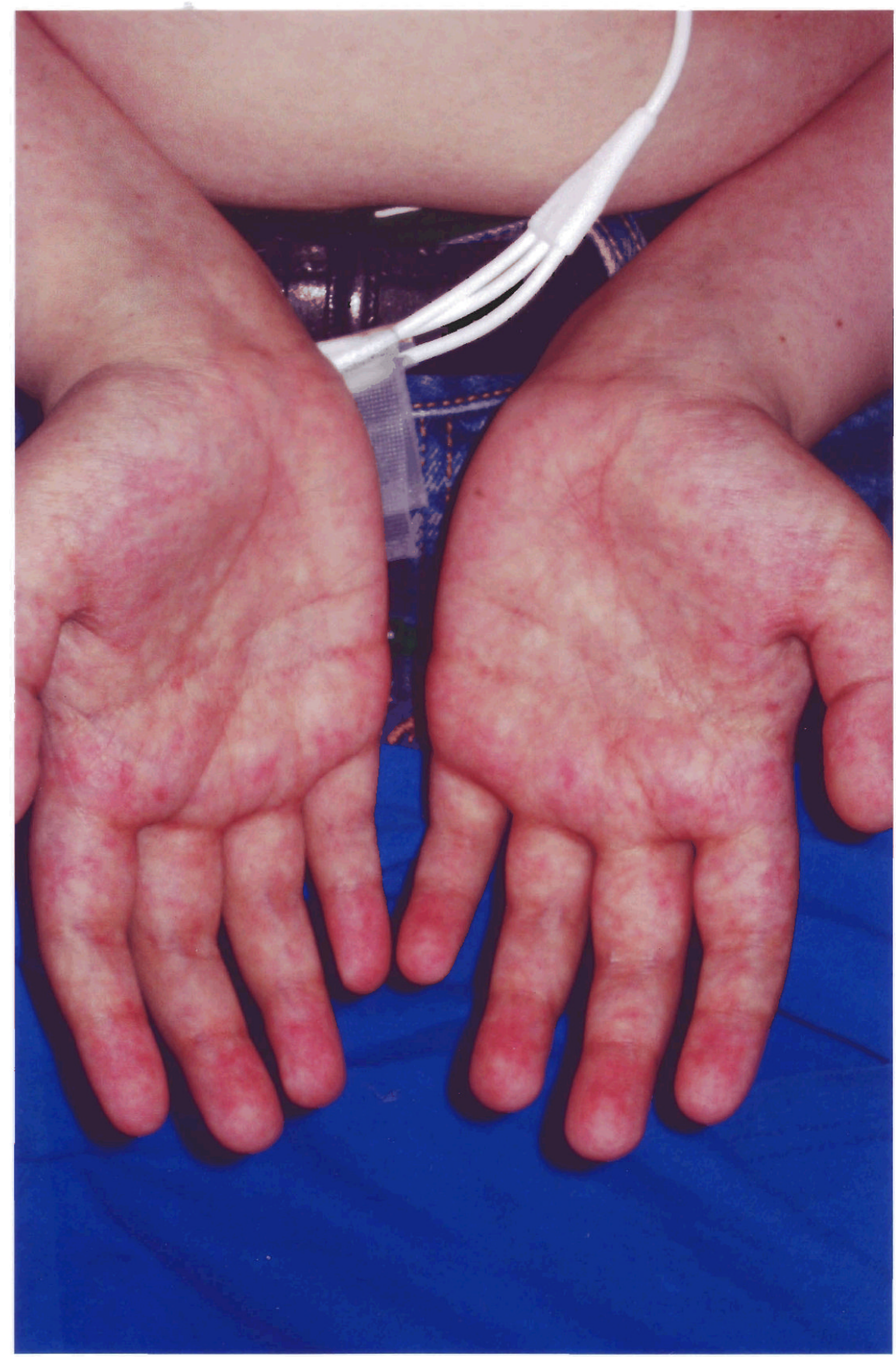

Figure 1. Acute GVHD of the skin (Grade I). Photograph courtesy of J. Levine, M.D. 


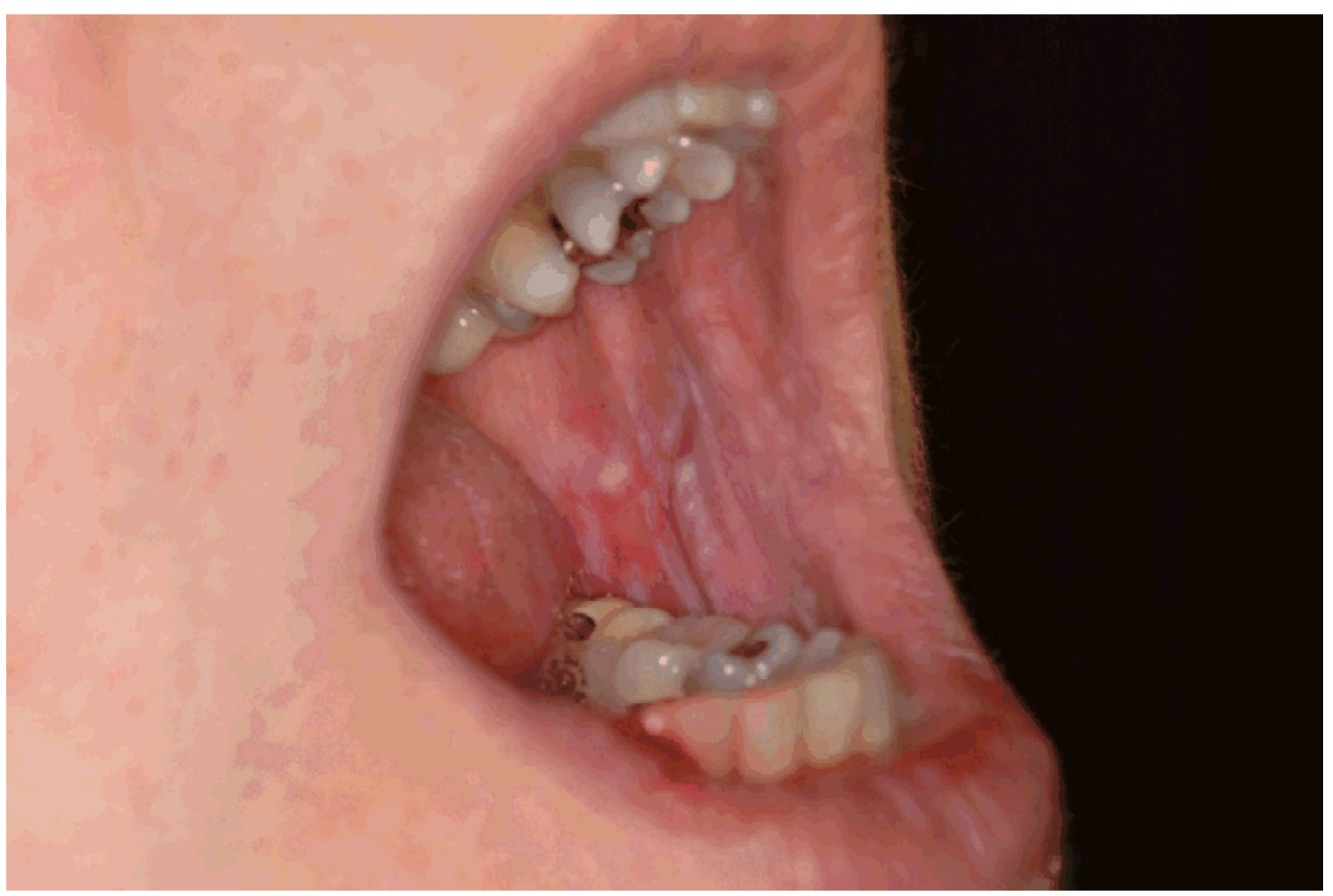

Figure 2. Chronic GVHD: Lichenoid changes of the buccal mucosa. Photograph courtesy of J. P. Guadagrini, D.D.S. 


\section{Conditioning: Tissue Damage}

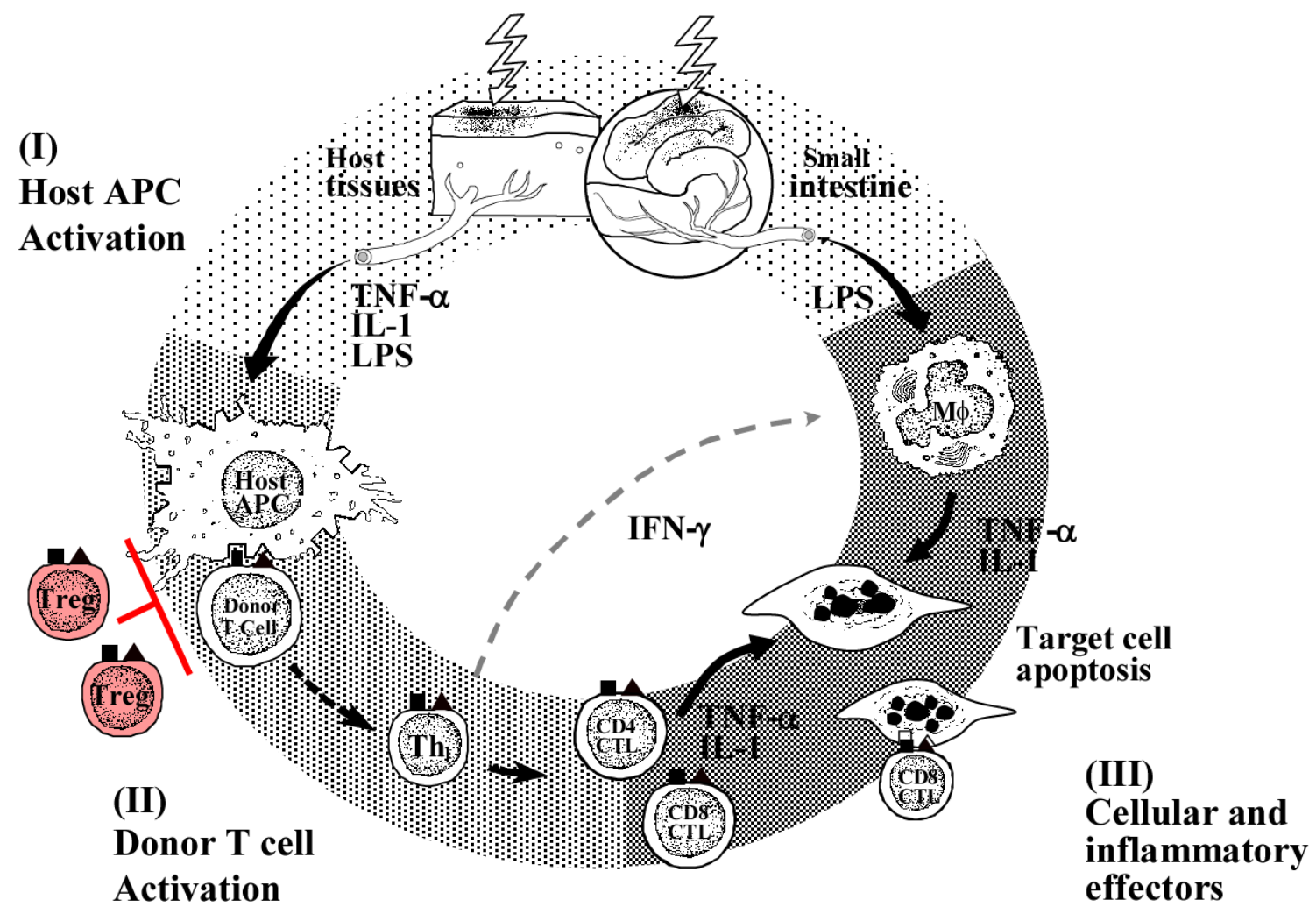

Figure 3. GVHD Pathophysiology

In Phase I, the recipient conditioning regimen damages host tissues and causes release of inflammatory cytokines such as TNF $\alpha$, IL-1 and IL-6. Increased levels of these cytokines leads to activation of host antigen presenting cells (APCs). In Phase II, host APCs activate mature donor cells. The subsequent proliferation and differentiation of these activated $\mathrm{T}$ cells produces additional effectors that mediate the tissue damage, including Cytotoxic $\mathrm{T}$ Lymphocytes, Natural Killer (NK) cells, TNF $\alpha$ and IL-1. Lipopolysaccharide (LPS) that has leaked through the damaged intestinal mucosa triggers additional TNF $\alpha$ production. TNF $\alpha$ can damage tissue directly by inducing necrosis and apoptosis in the skin and GI tract through either TNF receptors or the Fas pathway. TNF $\alpha$ plays a direct role in intestinal GVHD damage which further amplifies damage in the skin, liver and lung in a "cytokine storm." 
Table 1

Acute GVHD Symptoms

\begin{tabular}{|l|l|}
\hline Skin & maculopapular skin rash \\
\hline upper GI tract & nausea and/or anorexia PLUS positive histology \\
\hline lower GI tract & watery diarrhea $\geq 500 \mathrm{ml}+/$ - severe abdominal pain $+/$ - bloody diarrhea or ileus (after exclusion of infectious etiology) \\
\hline Liver & cholestatic hyperbilirubinemia \\
\hline
\end{tabular}


Table 2

\section{Chronic GVHD Symptoms}

\begin{tabular}{|l|l|}
\hline Skin & Dyspigmentation, new onset alopecia, poikiloderma, lichen planus-like eruptions or sclerotic features \\
\hline Nails & Nail dystrophy or loss \\
\hline Mouth & Xerostomia, ulcers, lichen-type features, restrictions of mouth opening from sclerosis \\
\hline Eyes & Dry eyes, sicca syndrome, cicatricial conjunctivitis \\
\hline Muscles, fascia, joints & Fasciitis, myositis, or joint stiffness from contractures \\
\hline Female Genitalia & Vaginal sclerosis, ulcerations \\
\hline GI tract & Anorexia, weight loss, esophageal web or strictures \\
\hline Liver & Jaundice, transaminitis \\
\hline Lungs & Restrictive or obstructive defects on pulmonary function tests, bronchiolitis obliterans, pleural effusions \\
\hline Kidneys & Nephrotic syndrome (rare) \\
\hline Heart & Pericarditis \\
\hline Marrow & Thrombocytopenia, anemia, neutropenia \\
\hline
\end{tabular}




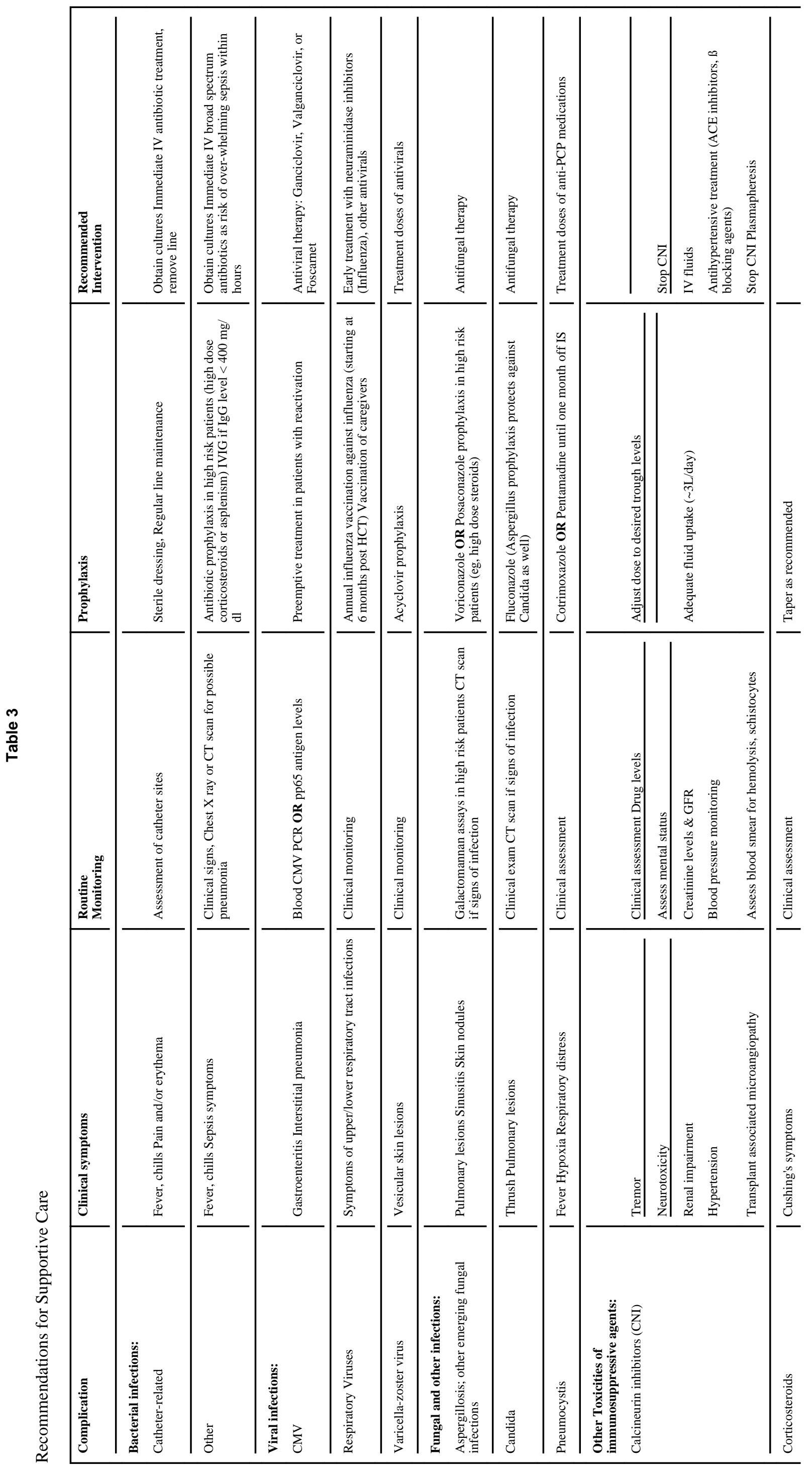

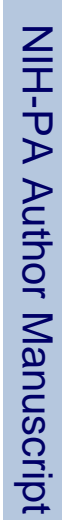

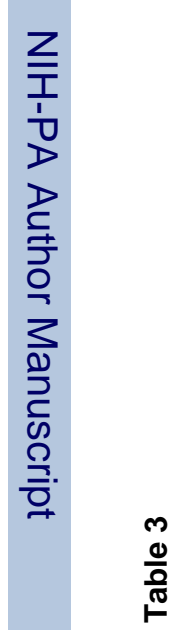




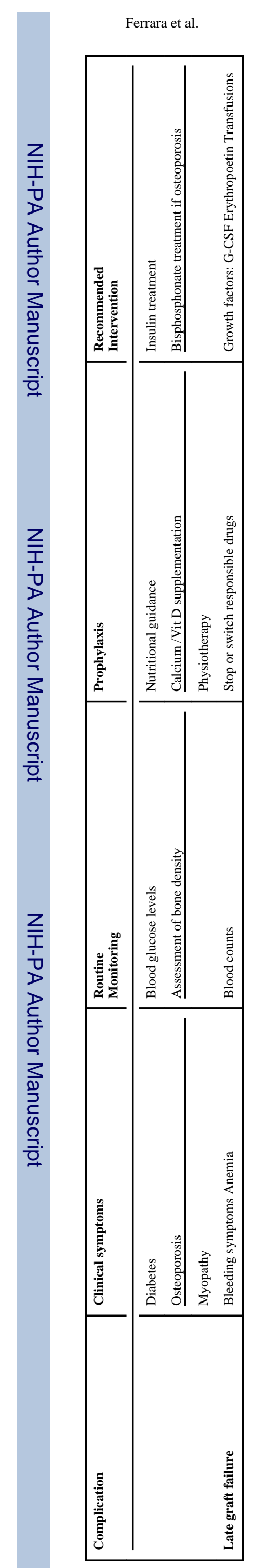

Page 25 